\title{
PHILIP FRENEAU'S MANUSCRIPT OF "THE SPY"
}

\author{
BY PHILIP MARSH
}

A LITTLE more than a year ago, Dr. Marsh, author of a number of articles on Philip Freneau, visited the Library in order to gather materials for a larger study, which has since then been completed. The following article is a byproduct of this larger work. The author, a graduate of the University of Maine, holds a doctorate from the University of California at Los Angeles. He is at present a member of the Department of English at the California Institute of Technology.

\section{I}

N Pattee's Poems of Philip Freneau is a fragmentary play in verse and prose called "The Spy," based on the story of Major André and General Arnold and their attempt to deliver West Point to the British forces in 1780 . Of the play, Pattee says: ${ }^{1}$

This fragment of a drama, as far as I can find, was never published. Freneau, judging from indications, wrote it shortly after his "Prison Ship," in the autumn of 1780 , only a few weeks after the events took place which it records. It exists, as far as I know, only in Freneau's fragmentary and much-revised autograph manuscript now in the possession of Miss Adele M. Sweeney of Jersey City.

Paltsits also says, commenting on the play, "I have seen a fragment ... e eight concluding lines of Act $4 \ldots$ the remainder consists of Act 5, Scene I." This piece is not included in Pattee, and its owner is not known. The fragment in Pattee extends to Act III, Scene IV, which is unfinished.

"The Spy" tells the story of General Benedict Arnold, his love of money, and his corruption by Major André. As Sir Henry Clinton's agent, André journeys from New York to West Point, offers Arnold I0,000 guineas for the delivery of the fort and an equal sum for the capture of General Washington. Arnold agrees, and a plan is formed. On his attempt to return-apparently, though the capture does not appear in the fragment-André is captured. Arnold, exposed as a traitor, escapes. The fragment ends at this point, in Act III, Scene IV.

1 Fred L. Pattee, Poems of Philip Freneau (Princeton, I902-1907), II, 39.

2 Victor H. Paltsits, $A$ Bibliography of the Separate $\xi^{\circ}$ Collected Works of Philip Freneau (New York, 1903), pp. 39-40. 
There are also scenes of a courtship and farewell between André and his lady love, Lucinda. There are songs sung by Lucinda, and the peasant-soldiers enliven the action, most of which occurs at or near West Point. From the piece that Paltsits examined, it seems that Act $\mathrm{V}$ was largely about André's trial, conviction, and execution.

The manuscript that was Pattee's source is now the property of the Rutgers University Library. It is found in Freneau's notebook, which contains his geometry notes, the log of the Rebecca and the Teneriffe accounts of I 779, the poem "The British Prison Ship," the prose narrative "Some Account of the Capture of the Ship Aurora," and "The Spy." Lewis Leary has published two accounts from this notebook: "The Log of the Brig Rebecca" and "The Manuscript of Philip Freneau's The British Prison Ship."' In I 899, Jay Milles published a monograph with a copy of the account of the capture of the Aurora. ${ }^{4}$ But not since Pattee has any study been made of "The Spy."

Part of the manuscript has been lost since Pattee examined itthe portion appearing in his Volume II, pages $67-70$, beginning with "2nd P. How like you that?" and ending approximately with "But everything seems." The rest is similar to Pattee's copy-with, however, many differences.

To make for more readability, Pattee has rearranged the paragraphing of the dialog, inserted italics, punctuation, and capitals, changed certain spellings, filled out abbreviations, and so on. Most of the changes are agreeable. But there are many mistakes, along with insertions, omissions, and substitutions, some of which change the meaning. For example, in Pattee (page 42), Sir Henry says (line 7), "found them to submit," while the manuscript says, "forcd them to submit." Pattee (page 43, line 25) has made into one long line what Freneau wrote as two: "That I do correspond with daily. O Britain, Britain." Pattee has "communicated" (page 44, line I 5 ) for "communication," and "sold" (page 45, line 3) for "sole."

Such errors, generally, do no great harm, and often, as in the case of "sold" for "sole," make good sense. Yet their frequency"I wrote him straight" (page 46, line I 5) for "strait I wrote him," "desperate" (page 48, line 2) for "despisd," "unequalled" (page 50, line 3) for "unsully'd," “my country" (page 50, line 33) for

${ }^{8}$ Journal of the Rutgers University Library, v, 65-70; vi, 1-28.

4 Jay Milles, Some Account of the Capture of the Ship Aurora (New York, 1899). 
"so many"-is so great as to cause the reader of the manuscript to wonder when the editor is to make a really serious mistake.

A whole line has been omitted by Pattee (page 50, after line 29): "Whene'er this magical delusion ceases." The substitution of "Charlestown" for "Carolina" on (page 5 I, line 25), "Samson" for "garrison" (page 53, line 9), "proud soul" for "second soul" (page 53, line I3), "life-restoring" for "life destroying" (page 55, line 8 ), and "you need to" for "you used to" (page 57, line 8) are apparently the results of carelessness, though the manuscript is often difficult to decipher. Nearly all of these mistakes are poor substitutes for the original.

The first speech by Pasquin in Act III (page 59), instead of "blows terrifically and there is heavy rain," should read, probably, "blows a humming Northeaster with heavy rain." And it is in this part of the play that Pattee has made the most implausible, even inexcusable errors. For his "Enter Pasquin" (page 60), the manuscript reads, "Enter Servt. Pasq." - and the servant who then speaks is not Pasquin, but Jeffery. Pattee's copy reads thus:

Pasquin. Sir, there is a traveller just alighted at Sergeant Jones's quarters, who desires to know whether he can have a little private conference with you, and asked me whether you were alone or no.

This speech, however, is cancelled in the manuscript in which Freneau has allowed the following to stand:

JEFF. There is a traveller just alighted at Sergeant Jone's quarters, who begs your Leave to be admitted within the Gate, and asked me whether you had company to night or not.

In Act III, Scene IV (pages 70-72), Pattee has mistaken "Off." for "Jeff." - and since Jeffery is a servant of humble personality, the dialog assigned to him is incongruous. In the introductory stage directions, Pattee has omitted "Enter an officer of the guard," having placed it at the end of the preceding scene. In the manuscript, this item is in Scene IV, and explains the nature of the dialog, a series of questions by an officer seeking Arnold, and Arnold's aide. But the line is not as Pattee has it. It is as follows: "Enter an officer with a Guard," which changes the meaning. Corrected, Scene IV begins with the officer and his guard entering Arnold's apartment, the aide receiving the officer and answering his questions. 
Drastic corrections must be made in this scene. The first speech is a question, not by the aide, but by the officer who has just enteredand quite naturally, since he is seeking to arrest Arnold, and the aide is of course the one who can answer the question. The second speech is not by "Jeff," but by the aide, who answers the question; and its fourth line should read, "So am I told by his attendants here." The last two lines of this speech in Pattee are in reality the officer's second speech, embodying his second question of the aide. A portion of "Jeff's" third speech (the officer's fourth, in the manuscript) has been omitted. The only way to set the reading straight is to present a full quotation of the scene from the manuscript. It follows, and should be compared with Pattee, Volume II, pages 70 to 72 .

Enter an officer with a Guard

Aid to Gen. Arnold-Scene, another Apartment in [illegible] House- -

Off.-is General Arnold here?-

Aid-Two hours have hardly yet elaps'd since he

Across the River to the Garrison

On some important business went in haste-

So am I told by his attendants here,

For since the General parted I arrivd-.

Off: Is he then at the Garrison-by heaven

We'll have him in a trice-

Aid-Yo' ull have him in a trice-Pray what means that

Off. I see your ignorance my honest friend-

Why such a damn'd un-natural Plot has happend

That when I mention it-if you have feeling

At the first word your blood must chill with Horror

And admiration sieze your very Soul-

This Traitor Arnold! - This vile abandond traitor

This monster of ingratitude unequall'd

Has been conspiring with an English Spy

To render up the fort to General Clinton-

Aid-What fort-the fort at West Point? Mean you

Off. The fort at West Point, on my sacred honour

The Garrison The Cannon and the Stores

And what is more the person of our Leader-

Five Thousand Troops at York are now embarked

And even sail [?] this night to take Possession

[line blurred and torn] 
Aid-Is, this reality - sure you are jesting-

And yet your serious [illegible] countenance

Lips that quiver, Eyes that glow with Passion

Tempt me to think your story may be true

And yet I doubt it - came you here to sieze him-

Off. Nay doubt it not-I have the Papers with me

That at a Glance betray this horrid treason

Aid-For what could he do this-

Was it Resentment Avarice or Ambition

That prompted him to act the traitors part-

And yet I'm sure it never could be Avarice

His country lavishes her wealth upon him

$\mathrm{He}$ has the income of a little king

And perquisites that by a hundred ways

Not only the bare wants of Life supply

deck him out

But raise him up to elegance \& Grandeur-

Perhaps indeed he has ambitious Views

Aims to make his court to Britains King

And rise upon the ruins of his country-

Perhaps it is resentment and disgust

For many hate him and have often said

He fattens on the plunder of the public

Off-Tis Avarice Sir-that base unmanly motive

The Glare of British Gold has captivated

This Hero as we thought him-what a curse

That human Souls can of such stuff be moulded

That they, foregoing fame and character

Can for the sake of what is despicable

Be foes to Virtue and to Virtue's friends-

But such are to be found and every age has seen em

Who for the sake of some external show

Some qualities that seemed at first attractive

[end of manuscript]

The play seems to contain too little dramatic force and action, and to be too largely taken up with soliloquies and oratory in the fashion of Shakespeare, or perhaps of Dryden. The dialog is stiff and unrealistic. But the oratory is spirited and sincere. Revised-and the manuscript looks like only a first draft-it might have been an interesting play in 1780 or $178 \mathrm{I}$, when the capture and execution of André, and the treason of Arnold, were highly interesting subjects. 